\title{
Rowena Coles
}

University of Urbino, Faculty of Education

rowena.coles@uniurb.it

\section{Domesticating the Trauma of War in Translation}

UDK: 81'255.4:82-93-31GLEITZMAN]=111, primljeno / received 15. 9. 2011.

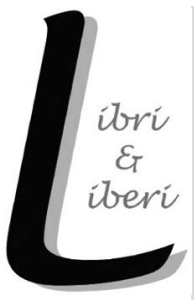

The paper is a comparative study of the novel Once by Morris Gleitzman written for children in English and of its Italian translation. First a brief examination is made of what is meant by the terms 'domestication' and 'foreignization' in translation. Domesticating a text aims at bringing the text, through translation, closer to the culture of the implied reader, to the image of childhood of that culture, and to the established canons governing children's literature in that country. Foreignization is a strategy that aims at preserving as many of the linguistic and cultural differences of the original as possible. The two cultures lying behind the languages in question are considered, with particular reference to how such cultural differences affect childhood. The analysis itself starts with an examination of the book covers, in consideration of the fact that covers, as part of the paratext, play an important role in the presentation of a book on the market. Three phenomena are identified that have brought about significant changes in the target text. Selected examples show several differences between the original and its translation in the syntax, the register and the linguistic creativity. In general, the three phenomena point to a process of normalization. It is concluded that in the translation of this novel a domesticating strategy has been used which has adapted the text in order to make it more acceptable to the Italian child reader, or at least to what Italian adults believe is more suitable for such readers. The trauma of war present in the Italian version has, consequently, been rendered somewhat less harsh and shocking.

Keywords: child reader, culture, domestication, facilitating, translation, normalization

\section{Introduction}

\section{The Story}

This paper examines the Italian translation of the story Once, written for children by Morris Gleitzman, the well-known Australian writer. The story tells of the traumas of war as seen through the eyes of a nine-year-old boy, Felix. It is set 
in Poland in 1942. Felix has been placed in an orphanage by his Jewish parents to protect him from the Nazis. He manages to escape from the orphanage with the aim of finding his parents, but this escape leads to a series of harrowing experiences that put an end to his innocence. He builds up a close friendship with a younger girl, Zelda, whose parents' killing by the Nazis has been witnessed by Felix. Felix and Zelda find themselves being herded along the road with other Jews, they are kept hidden in a cellar, and nearly suffocate in an over-crowded boxcar from which they throw themselves at the close of the story. However, Felix manages to distract all his fellow sufferers, and even a Nazi suffering from toothache, with his storytelling. By the end of the story, Felix is only too aware of the traumas of war - the evil of the Nazis and the fate of the Jews, the Concentration Camps, the dramatic splitting up of families, but he shows how imagination can produce amazing resilience. Felix remains, despite the traumas he lives through, the eternal optimist: "Everyone deserves to have something good in his life," he declares, "At least once. I have. More than once." $\left(2005^{1}: 150\right)$

\section{Domestication vs. Foreignization}

This study shows how the story has undergone a process of domestication in its Italian translation. Domestication is a translation strategy that is based on an adherence to domestic literary canons and, as Eugene Nida claims, produces translations that "relate the receptor to modes of behaviour relevant within the context of his own culture" (1964: 159). This process is in contrast with 'foreignizing,' where the translator maintains a close adherence to the foreign text, motivated by the desire to preserve the linguistic and cultural differences of the original. The difference is summarised by Riitta Oittinen: "In simple terms, while domestication assimilates texts to target linguistic and cultural values, in foreignization some significant traces of the original text are retained" (2006: 42). Domestication is the most common strategy used by translators of children's stories, inspired by the idea that the passage of children's texts into the new language should be eased by accommodating what is culturally foreign, and therefore strange and unfamiliar, into the target language and culture. Thus the translator aims at rendering the foreign text manageable for its young readers.

With regard to the translation of children's literature, domestication and foreignization are very delicate issues. Some authors believe that children must be put in a position to appreciate the foreign in the translated texts and thus see this

1 The references to the English vs. Italian editions of Gleitzman's book in the following text will be distinguished by the year of publication; 2005 vs. 2009, respectively. 
strategy as educating the child to tolerate 'otherness.' Lawrence Venuti, for example, has attacked domestication, claiming that domesticated translations "conform to dominant cultural values" and stating that foreignization does not just "signal the linguistic and cultural differences of the foreign text" but also "challenges the dominant aesthetics" (1995: 182-3). Others believe, like Oittinen, that the child reader "may very well be unwilling to read the translated text finding it too strange" (2006: 37). Oittinen also points out that "In the end, all translating for children inevitably becomes an activity 'guilty' of textual domestication," suggesting that "translators of children's literature should reach out to the children of their own culture" (ibid.).

The adoption of a translation strategy which reaches out to a child readership may be considered to be the one that facilitates the reader's task, thus a facilitation ${ }^{2}$ strategy, rather than a deliberate domestication as such. In support of this facilitation strategy Gillian Lathey claims: "A translator for children has to have a clear understanding of his or her audience [...] for the translation to be successfully received and enjoyed by young readers" (2006: 15). Also, Peter Hollindale talks of "drawing the translator towards accessibility" (1997: 46).

\section{Two Different Cultures}

In order to understand why certain domestication strategies are used in the translation of Once, we must first examine the two cultures of the languages we are dealing with in this paper - on the one hand an English-speaking Anglo-Saxon culture, and on the other an Italian-speaking Mediterranean culture. George Orwell in Inside the Whale and Other Stories (1957) refers to the difficulty of defining culture, but nevertheless humorously suggests that there are general traits and tendencies that a population shares: "National characteristics are not easy to pin down but nevertheless, nothing is causeless, and even the fact that Englishmen have bad teeth can tell one something about the realities of English life" (38). Perhaps it is more opportune to refer, when we use the term 'culture' to the out-of-awareness level which, as Brake et al. explain, “...is not just the tip of the cultural 'iceberg,' such as customs, rituals, gestures, but refers to "the most powerful elements of culture $[\ldots]$ that lie beneath the surface of everyday interaction. We call these value orientations" (1995: 34-9).

Edward Hall (1950/1990) identifies two basic cultural orientations - one based on low-context communication (LCC) where facts, directness and substance are

${ }_{2}$ Facilitation is a translation strategy used by a translator who adapts the original text to make it more easily understandable and accessible to the child reader of the translated text both from the linguistic and from the cultural point of view. 
high cultural values, and one based on high-context communication (HCC), where relationships, feelings and indirectness are important. David Victor (1992), with reference to Hall's theory, produced a cline between HCC and LCC cultures, placing Italian as tending towards a HCC and English towards a LCC. David Katan agrees with this analysis, identifying the typical features of high- and low-context operating modes. He claims that LCC places emphasis on "text/facts/directness/consistency/ substance/values" while HCC places emphasis on "context/relationships/feelings/ indirectness/felixibility/social/personal appearance/circumstances" (1999: 181).

Katan goes on to state that Italy tends to operate on a more tightly-woven high-context bias, while the British tend to operate on a more loosely-knit, lowcontext bias. With reference to the different value given to the expression of feelings between a LCC and a HCC, Fons Trompenaars (1993: 63) compiled a questionnaire asking the participants if they would express their feelings openly if upset at work. In the chart Italy scored $71 \%$ of people who would express their feelings as compared to the UK where $29 \%$ would not express their feelings, thus confirming the different value given to feelings between the two cultures. Katan even claims that English in its lexico-grammatical system is itself "decidedly LCC in comparison to many other languages" (1999: 184). More specifically, with regard to children's upbringing, Anglo-Saxon cultures encourage children, who grow up in a culture "which values individual freedom" (ibid.), to become independent and responsible at an early age, whilst Italian culture prefers to protect and pamper children, leading to the two widespread phenomena: 'mammismo' (excessive attachment to mother even in adulthood) and 'bamboccioni' (adults who are forever kids). Geert Hofstede confirms these cultural differences when he states: "The Italian mammas and nannies see dirt and danger in the piazza where the American grandparents see none" (1991: 79).

If, then, it is true that Once has undergone domestication in translation into Italian, we would expect the ways in which the trauma of war is translated to be affected by these cultural differences. We would expect, and indeed we find, a certain softening of the harsh realities that are contained in the original text.

\section{Book Covers}

The first part of the analysis regards a part of the paratext: the book covers. Paratexts typically include the cover, the title, the front and back matter and other material not directly traceable to the author. Before entering into detail, it is necessary to consider the functions of paratext. Philippe Lejeune describes the paratext as "a fringe of the printed text which, in reality, controls one's whole 
reading of the text" (1975: 45). And Gérard Genette identifies the important role of the paratext, describing it as a "threshold," and "a zone of transaction, a privileged place of pragmatics and a strategy, of an influence on the public, an influence that $[\ldots]$ is at the service of a better reception for the text and a more pertinent reading of it" (1997: 2).

Book covers are normally created by the publisher whose aim is to make the book attractive to buy. In this regard, Genette considers the paratext essential for the positive reception of the book, claiming that the elements of the paratext: "surround it (ref. the text), and extend it, precisely in order to present it, in the usual sense of the verb, but also in the strongest sense: to make present, to ensure the text's presence in the world, its 'reception' and consumption ..." (1). We may suppose then that the English and Italian publishers will attempt to make the cover interesting and appealing for their respective readerships, or to the adults who, while buying the book, may be looking for its suitability for the child reader. It will be seen in the analysis that the differences between the two book covers seem to reflect the cultural differences between the two readerships.

\section{Front Covers}

In the front cover of the English edition of the book (Gleitzman 2005) the title "Once" (Fig. 1) is written in bold at the bottom of the pale yellow cover in large Book Antiqua font. Above the title, in the same font, but smaller lettering, is the subtitle: "Everybody deserves to have some good in their life," where the words 'everybody,' 'deserves' and 'good' attract greater attention through their slightly larger character size. The phrase "At least" in Book Antiqua font is placed above the title of which it is syntactically part.

The illustration is of a railway track in grey, centred but narrowing into distance, with a small grey figure of a boy who seems to be jumping from a train, which is not visible on the tracks. In the top right hand corner is a golden yellow Star of David. Along the bottom are the tops of orange flames.

On the cover of the Italian edition (Gleitzman 2009), in three different shades of blue, the title "Una volta" (Once) is written in the centre (Fig 2). The characters used are not identifiable as a specific font in that they are a random mix of capital and small letters, often with an irregular slant, thus producing an original font similar to a child's writing. The sub-title is "La storia di Felix" (The story of Felix). Again the lettering is similar to the title: child-like.

With regard to the illustrations, at the top there is the bottom half of an old wooden boxcar crossing the page horizontally. Towards the bottom of the cover 
there are two children, stylised in cartoon-like form, running hand in hand - a girl of about 5-6 years and a boy a few years older. Their clothes and shoes seem to be clean and in good condition, their hair looks well-kept and they are smiling. Clearly indicated, top left, is the age of the target reader: " $9+. "$

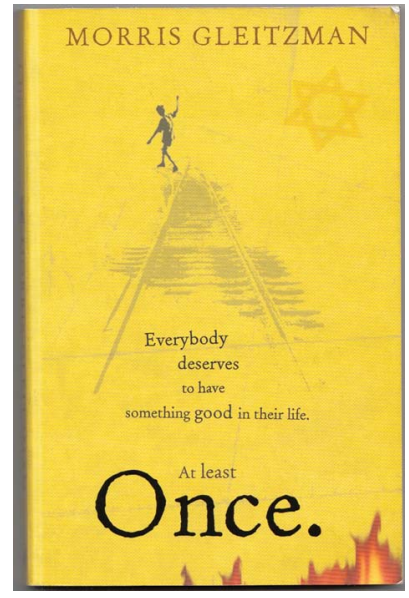

Fig. 1 The front cover of the English edition of Once (Gleitzman 2005).*

SI. 1. Prednja strana korica engleskoga izdanja romana Once (Gleitzman 2005)."

One of the most obvious differences between the two book covers is the colour used for the background. The English cover is pale yellow (to note as well is the golden yellow used for the Star of David). Yellow is the same colour as the Star of David that Jews had to wear under Nazism as a sign of their Jewish identity. It is also the colour of the badge used to identify Jews in the colour coding system of the concentration camps. Thus the English cover unites an implicit reference to the Holocaust (yellow) to an explicit reference to it (the Star of David). The scene depicted is stark. On the other hand, the Italian book cover uses blue, a colour which, besides being the national colour of Italy, the motherland, is also the colour associated with the Mother of Mothers (the Virgin Mary) - an important figure in Catholic Italy. Besides these two specifically cultural associations, blue symbolizes stability and calm. In this way the Italian cover uses a colour which is probably subconsciously reassuring for Italian child readers.

The railway track on the English cover leads away into the distance suggesting a journey into the unknown. The boy has decided to break the journey by jumping

* The images can be seen in colour in the electronic version of this issue. To view all the images in full resolution please visit $<$ www.librietliberi.org $>$. 
off. The track is reminiscent of well-known images of trains entering concentration camps, an intertextual reference. The illustration anticipates the book's contents in its symbolism (Felix takes decisions which will shape his life in jumping off the train of life's events, i.e. he runs away from the orphanage) and in reality (he does actually jump off the train taking him to a concentration camp).

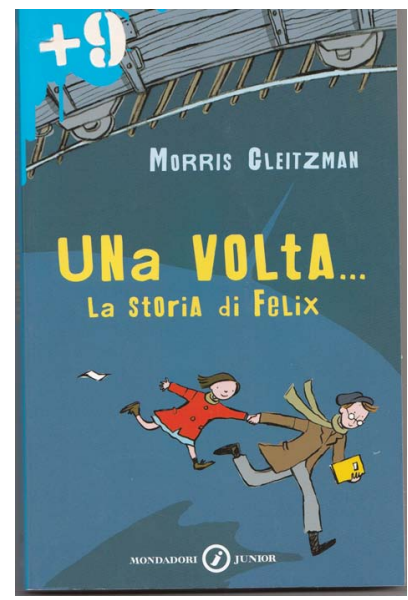

Fig. 2 The front cover of the Italian edition of Una volta (Gleitzman 2009).

Sl. 2. Prednja strana korica talijanskoga izdanja romana Una volta (Gleitzman 2009).

The Star of David, which is clearly visible on the English cover, is the symbol, as has already been stated, most commonly associated with Jewish people, and specifically with the Holocaust, and the one which most children (and of course adults) would immediately recognize and understand. Therefore, this explicit visual reference, linked to the implications of the railway track, would undoubtedly indicate to the majority of prospective buyers of the book that the story deals with the Holocaust.

The Italian book cover does not use railway tracks in the same way, but lays emphasis on the boxcar - on the front cover less evident than on the back, where the truck occupies almost half the page (Fig. 4). It is somewhat difficult to link the protagonists to the truck. The expression on the cartoon-style children's faces reflects no anguish. Therefore, the connotative meanings of the original cover are not repeated on the Italian one. The viewer can only suppose that the two children are running away from the truck for some reason. The explicit reference to the Holocaust through representation of the Star of David on the English cover is not reproduced on the Italian cover, either. 
The Book Antiqua font used in the original recalls the sort of lettering used in typewriting during the last World War, giving a historical and solemn clue to the setting of the story, whilst the irregular font types in the translation, in their resemblance of a child's way of writing, give a rather light-hearted impression.

In the original, no direct reference is made to the protagonist Felix. In fact, the subtitle "Everybody deserves to have something good in their life" lends a general, moralistic tone to the book. The contents of the book itself are hinted at by symbols, such as the Star of David, the railway track, flames. The information that the English-speaking reader gathers from the illustrations and words of the front cover is sobering and suggestive of danger, which requires the reader to deduce the contents of the book.

The reader of the Italian text is explicitly told on the front cover that $\mathrm{s} / \mathrm{he}$ is going to read a "story" about a boy called Felix, reflecting the more traditional canons of children's literature. Indeed, the Italian cover seems to be more carefree. Moreover, the children are dressed well, in colourful clothes, and it is rather difficult to associate them with the historical setting of the story.

In sum, the English front cover offers a greater challenge to the reader, in that an effort of deduction from the clues provided is necessary, whilst the Italian cover tends to mask the real contents of war and the Holocaust by offering a sort of 'shield' against their horrors, stating that the book is "the story of Felix". Moreover, further protection is offered through the indication of the age of the target reader $(9+)$, suggesting that the book is not suitable for children under that age. On the other hand, the English book cover carries no indication whatsoever of the age of the target reader.

\section{Back Covers}

In the back cover of the English edition (Fig. 3), there are three separate sentences: "Once I escaped from an orphanage to find Mum and Dad / Once I saved a girl called Zelda from a burning house / Once I made a Nazi with toothache laugh" placed one below the other. The cataphoric referent of the subject pronoun "I" is only reconstructed when the reader reaches the two statements lower right on the back cover: "My name is Felix. This is my story."

The illustration of the boy on the front cover is used again on the back cover. It is smaller, reversed and superimposed over the latter two statements, thus making a visual-verbal link between the figure of the boy jumping and the name Felix.

The back cover of the Italian edition (Fig. 4) has two textual parts. The first is placed towards the top left-hand side, and is superimposed in white lettering on the depicted part of a boxcar, coloured grey on an otherwise blue background. The text 
is the opening, word for word, of the fourth chapter in the book: "Once I escaped from an orphanage in the mountains and I didn't have to do any of the things one does when one escapes. Dig a tunnel. Disguise myself as a priest. Lower myself on a rope from nun's robes knotted together. I just walked out of the front door" (this and further back translations from the novel and translations from the Italian covers are by R. C.).

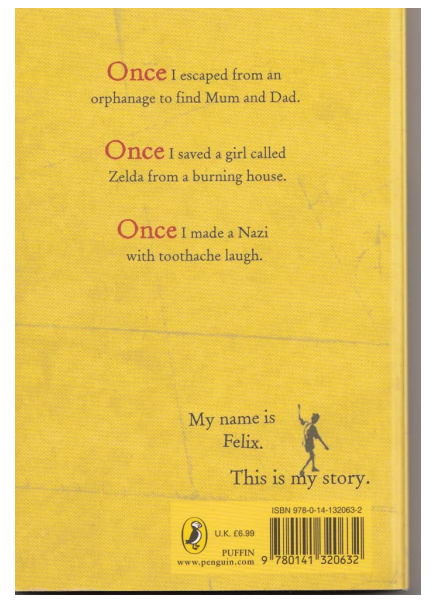

Fig. 3 The back cover of the English edition of Once (Gleitzman 2005).

Sl. 3. Stražnja strana korica engleskoga izdanja romana Once (Gleitzman 2005).

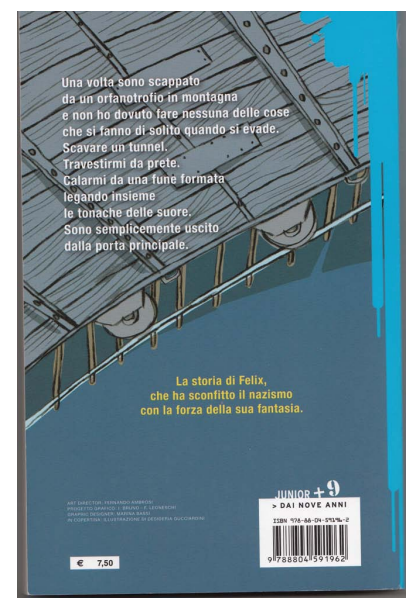

Fig. 4 The back cover of the Italian edition of Una volta (Gleitzman 2009).

SI. 4. Stražnja strana korica talijanskoga izdanja romana Una volta (Gleitzman 2009). 
Lower down centre, in yellow print, three separate lines read: "The story of Felix, / who defeated Nazism / with the strength of his imagination."

The regular, more classical Arial Narrow font on the back cover is in contrast with the original playful child-like font used on the front cover.

The back cover of the original edition first makes reference to three important plot events. The statements in English have no reference to any emotions - they just relate bare facts referring to the reality of war. Such a description would seemingly appeal to an English-speaking reader whose culture gives high value to physical conditions and facts. Katan says in this regard: "Inductive cultures are more pragmatic and specific, starting from empirical observation. Facts and statistics are highly valued. The USA and Britain are particularly inductive" (1999: 176). And yet, although facts are related simply, the impact is striking for a number of reasons. One is the author's use of syntactic and lexical repetition which produces a marked language use (repetition in unmarked use is normally avoided). Secondly, the information contained in the three simple sentences would have normally been concentrated into three coordinated sentences, with ellipsis of 'once' and 'I,' thus the author (or the publisher) has chosen a marked type of syntax. Finally, the word used for the title on the front cover ("Once") is repeatedly recalled, and the foregrounded time adverbial is awarded further visual marking by the colour (red) and the larger font size used. Moreover, the striking impact of the statements is supported by the fact that these exceptional and dramatic events are related through a normal syntactic form - the simple sentence - giving the impression of a list of routine actions; a sort of understatement, highly valued in the Anglo-Saxon culture. The three sentences are therefore the product of a foregrounding strategy achieved by using marked linguistic devices as described in what John Douthwaite calls "the transgressive manipulation of language norms" (2000: 346). Such manipulation gives an illocutionary force to what is in fact only superficially a plain list of facts.

The English cover presents a first-person narration as in the novel itself (this aspect will be examined in detail later). Felix speaks directly to the reader. In contrast, the Italian back cover, referring to the first main event in the plot (Felix's escape from the orphanage) takes on rather a light, humorous tone, which tends to disguise the harsh reality of the story. In Italian, a strong statement is made: "The story of Felix who defeated Nazism with the strength of his imagination." This statement is made using a third-person narration, with the narrator making omniscient judgements on Felix, thus acting as the interpreter for the child reader. This hyperbolical statement seems to give Felix superhuman, heroic powers, stimulating emotions of amazement and wonder, and thus appealing to Italian readers as those of a HCC, as we have previously seen. 
In sum, the images and the printed text on the original book covers are based on presenting the harsh reality of a war-time story, whilst the Italian covers seem to camouflage such harshness. The latter have softer images and present the book in a more delicate tone, relying on the more humorous aspects of the book as its attraction rather than on more dramatic episodes. The covers reflect the cultural values of the languages in which the texts are written. It is worth recalling that the paratext is normally an editorial decision, and that paratexts may occasionally be incoherent in their message with the text itself. However, in this case it seems that the editor of the Italian edition, like the translator, has used a domesticating strategy, producing a different cover from the original one, which is then more agreeable to Italian cultural norms and therefore more attractive to the prospective Italian buyer. Obviously, the illustrative nature of the book covers must have a strong impact on the book browser, and convince him/her that this is the book to buy. So editors inevitably try to produce a product with which the readership can immediately identify.

\section{Translation Text}

We will now examine the translation proper. For reasons of space, only a few examples can be given, but they will show how the translator's domestication strategy adapts the story to the Italian culture. Examples reveal three general transformations which may be seen to have taken place in the translation process: changes in the syntax, normalization ${ }^{3}$ of lexical creativity and change in register. It will be seen that the three phenomena lead in general to a certain normalization of the translated text.

\section{Change in Syntax}

The first example shows a change in modality and regards the translation of Felix's statement in reference to the orphanage, "Everyone here is meant to have dead parents" (2005: 3) meaning: everyone here ought to / is supposed to have dead parents. The verbal phrase 'to be meant' is a semi-auxiliary verb of modality and modal verbs are, as The Oxford Dictionary of English Grammar states, the expression of the speaker's opinion about likelihood or obligation. Quirk et al. claim such verbs have "tentative inference" (1985: 144). The statement in hand

3 Normalization may be defined as unmarked language use in a specific context, whether syntactical or lexical - a tendency towards textual conventionality. Douthwaite describes normalization as what "constitutes normality (the typical pattern)" (2000: 312). An example of lexical normalization is the substitution of "needles of light pricking through the gloom" (Gleitzman 2005: 84) with "rays of light in the half-darkness" (Gleitzman 2009: 115). 
has a subtle touch of irony - it suggests that 'having dead parents' is the requisite for gaining access to the orphanage, but, as the child reader knows, this is not Felix's case. In fact it was Felix's parents who left him in the orphanage in order to save him from the Nazis. The original expression reveals striking marked language use. Whilst an orphan's condition is more frequently expressed in English describing parents who are dead, here the orphaned children (i.e. everyone here) are the subject of the concept 'to have dead parents.' Thus we can compare the more common, unmarked: "everyone's parents are dead" with the unusual, marked statement: "everyone has dead parents." The impact of this latter statement is stronger precisely because of the unexpectedness of its form.

On the other hand, the Italian version makes a bland statement of fact: "If one is here it means that one's parents are dead" (2009: 8), where the tentative inference and subtle irony of the original are not reflected, and the modality has disappeared. A simple, explanatory equivalence is made: if one is here = one's parents are dead. Douthwaite (2000: 353) has noted that sentences constructed on the verb 'to be' are structurally uninvolved and conceptually elementary, and this is the case here. In fact, the Italian version does not transmit the complexity of the English expression. Neither does it have such a strong impact as the original, because the markedness of the original (to have dead parents) undergoes a process of normalization in the translation (parents are dead).

In the second example some simple sentences have been converted into compound sentences in the Italian version with consequent loss of pauses. Such pauses serve in the original to reflect how Felix's thinking is developing; not as a flowing stream of thought, but as a sudden, abrupt realisation of the consequences that his imagined actions will have on his future. So we can compare the English original text (2005: 5):

Then I stop. I'll have to say good-bye to everyone here soon. That makes me feel sad. And when the other kids see Mum and Dad are alive, they'll know I haven't been truthful with them. That makes me feel even sadder.

with the Italian version, which loses this staccato effect (2009: 10-11):

I stop immediately, however. Soon I'll have to say good-bye to everyone and this saddens me. Moreover, when the other kids see my Mum and my Dad are alive, they'll understand I haven't been truthful, and this saddens me even more.

The translation reduces the stark impact of the original, where thoughts come in rapid succession. The Italian reader is also helped by a greater explicitness through the use of connectives ("however," "moreover") not found in the original

In the third example regarding syntactical change, the original text has a 
marked sentence form based on ellipsis, whilst the translation reintroduces the elliptic forms. In this passage Felix closes his eyes and thinks about the baths Mum and Dad used to give him. He compares these baths of the past with the baths of the orphanage. He then goes on to think about three other things: "In front of the fire with clean water and lots of warm wet cuddles and lots and lots of stories" (2005: 8). It is a pragmatic thought process, reflecting the preference in English-speaking cultures for 'thinginess.' Indeed, Michael Halliday talks of "a general drift towards thinginess" (1992: 59) in English from a linguistic and conceptual point of view. The quoted sentence is not a normally structured sentence in that both subject and verb are missing. In fact, it is composed of two phrases that have been upgraded to a sentence creating a striking marked syntactical form. In the Italian version Felix thinks about his parents carrying out the bathing activities, focusing attention on the people and their relationships and feelings - the processes rather than the objects - and thus appealing to Italian cultural preferences: "in the clean water, by the fire, they covered me in cuddles and told me stories one after another" (2009: 14). The situation is the same, but it is seen from different viewpoints: LCC vs. HCC. From a structural point of view, we can note that the stylistic expressivity of the upgraded structure of the original has been lost through the re-instatement of the omitted subjects and verbs.

The next example shows how the original text undergoes a process of refinement in the translation, but in this transformation, the child-like tone of the original syntactical pattern is undermined: One of the chapters opens thus in English (2005: 90):

Once I escaped from an underground hiding place by telling a story. It was a bit exaggerated. It was a bit fanciful. It was my imagination getting a bit carried away.

The repetition (marked language use) and the short, abrupt, equivalent sentences create the feeling of a small boy trying to find excuses for not telling a good story with a sense of urgency. The Italian version does not use any repetition and articulates the sentences in a more complex syntactical form which does not capture the tone of the original (2009: 123):

Once I escaped from an underground hiding-place by telling a story. It was rather exaggerated, somewhat fantastic. I let myself be transported a little by my imagination.

The syntactical forms (and the vocabulary used) give the impression of an adult's stream of consciousness, rather than a child's.

Yet another example shows how the translator, perhaps in an attempt to present a more elegant style, avoids using the repetition of the original, where it plays a forceful role. In the following passage, the impact of the repeated phrase "like I 
remember" strongly underlines Felix's anguish, a feeling that he is too young to explicate in words (2005: 38):

It's just like I remember. Well almost. The street is narrow like I remember and the building are all two levels high and made of stone and bricks with slate roofs like I remember.

The Italian version does not repeat the phrase "like I remember" in what seems to be a deliberate attempt to avoid using the same expression (2009: 54):

It is exactly like I remember it. Or almost. The street is narrow and the buildings are all on two floors, in stone and brick with slate roofs, just like then.

\section{Normalization of Lexical Creativity}

In the following examples, we can see how nominal groups, which are, in the original, striking in their originality and strong in their impact, are toned down through a normalization process in the translation. Gleitzman has given the Englishspeaking Felix a narrating voice that is that of a nine-year-old boy, but is in addition awarded a notable degree of lexical creativity, producing an easily distinguishable idiolect that we come to identify as Felix's voice. In this regard we must remember that Felix's parents are cultured book-sellers (his parents used to tell him "lots and lots of stories" (2005: 8), and Felix prides himself in being a storyteller. In fact, his ability to tell stories is the gift that enables him to survive ("Once I escaped from an underground hiding place by telling a story”) (2005: 90) and indeed to help others to survive (2005: 66):

Once I spent about six hours telling stories to Zelda to keep her spirits up, to keep our legs moving as we trudge through the rain towards the city.

The following examples show how it is this very quality of Felix's narrating voice that changes in translation, where often the creativity of the original is lost in a normalizing translation process.

The first example refers to the nominal group "jealousy riot" in Felix's statement "If others see my carrot there'll be a jealousy riot" (2005: 3). The expression, of striking lexical creativity in English, is paraphrased and explicated in Italian into two coordinated clauses: "... they would be jealous and a riot would break out" (2009: 8). The English expression provides linguistic entertainment which is lost in translation. Moreover, the English-speaking child reader has to elaborate the logical connection between jealousy and riot, while the Italian reader has the connection 'served up on a plate,' as it were, reflecting the translator's facilitating strategy.

In the second example, Felix's thoughts are suddenly interrupted, without any previous explanation, by the phrase "Felix Saint Stanislaus" (2005: 3). The 
English reader cannot understand, at this point in the story, why someone is adding a Saint's name to Felix's. Only after a few lines can the reader understand that Saint Stanislaus refers to the table where Felix sits. We must ask why this is not made clear immediately by the author, and we can suppose that it is meant to keep the reader a little in the dark and encourage him/her to read further. Not so for the Italian child reader, who is told in the translation immediately that Saint Stanislaus is the name of the table at which Felix sits: "Felix, table Saint Stanislaus" (2009: 8). To be noted, also, is the authoritarian impact of the order given in the original, seemingly less harsh in translation.

The third example also shows how the stylistic expressivity of the original is toned down in the translation. The passage (2005: 6) reads:

Now's the moment. The bath selection has just started. Mother Minka is standing in the front, checking Josef all over for dirt.

The expression "bath selection" is explicated in Italian as "the inspection for baths." In the original it is not immediately clear what the bath selection is, but the expression has obvious shades of meaning associated with concentration camp gassings. With regard to the connotative value of words, Margherita Ulrych (1992) points out that it is at the level of connotative meaning that we judge and react to words. These are "the culturally or socially determined value judgements that are implicit in the semantics of words." On the contrary, the Italian child reader is put in the know straight away through the translation's facilitating paraphrase which explains that the procedure is a simple inspection of the orphanage children to see who needs a bath. In this way the dramatic association of the English text between the routine bathing at the orphanage and the Holocaust has been removed in the translation, which produces an innocuous expression devoid of an implicit reference to the horrors of war.

Another expression of harsh impact in the original is the term "pig-slaughterer." It is found in the passage where Felix tries to let his friend have the first bath (2005: 7):

I hold my breath and hope Dodie didn't hear me. He actually wants to be a pigslaughterer and I'm worried he might say something.

The connotations of the word 'slaughter' are dramatic. In fact the The Oxford Concise Dictionary (OCD) (1999) gives the following two definitions: "i. the killing of farm animals for food ii. the killing of a large number of people in a cruel or violent way." The English-speaking child reader would no doubt be shocked by the term being used in relationship to a child's desire for a future job. The Italian version waters down this shock-producing effect in the use of the normal Italian word for butcher (macellaio) - an unmarked term in translation for a marked term in the original. 
The final example regarding the normalization of lexical originality is found in the description of the bland soups to be consumed in the orphanage. The translation fails to grasp the original creative strength. So "flecks of cabbage" become a more scientific sounding "fragments," "tiny blobs of pork fat" become more refined "little drops" with a consequent loss of onomatopoeia, and finally the description of the emotional state of the lentils, which are "lonely" in the original, mirroring Felix's emotional state, becomes a simple reference to an objective physical state: they are "drifting" (2005: 2; 2009: 6).

\section{Change in Register}

The third phenomenon is perhaps the one that leads to the most significant changes in the translation. In order to understand the full implications of this phenomenon, it is important to understand what is meant by register. Register is described by Halliday in his Functional Grammar as "variety according to use" (1985: 43). Christopher Taylor states that "register refers to what a person is doing with language at any given moment" (1998: 147). Closely linked to register is the concept of discourse community which refers to the variety of language adopted by a group of people involved in a common task or event. The register used in Once is the one Taylor identifies as an aged-based variety (115). In fact Felix, who is the first person narrator of the story, uses a variety of English that is typical of a child of about 9-12 years of age. The discourse community that he is most frequently part of in the story is the community of children of a similar age.

An analysis of a short passage taken from Once illustrates the main characteristics of this particular age-based variety of English (2005: 124):

I slip quietly out of our building without anyone seeing me.

The ghetto streets are different tonight.

They're just as dark and scary and full of litter as always, but not so deserted.

Nazi trucks are zooming around. German soldiers are running in and out of apartment blocks. In the distance I can hear shouting.

We can note the following characteristics: short sentences with simple syntax, typically boyish words such as "scary" and "zooming," and the use of present tense conveying a sense of child-like immediacy and instantaneity. John Stephens states that the present as a narrative tense, suppresses "any suggestions that the outcome is knowable in advance" (1999: 78-9).

In the translation, Felix seems to have a different narrating voice, a more adult, formal voice, as will be seen in the examples that follow. With regard to narrating voices, Emer O'Sullivan (2003: 201) has identified both in the Source Text and the Target Text i) a narrator (the one who tells the story, whose voice is audible when 
the story is told), ii) a narratee (in the words of Barbara Wall "the more or less shadowy being within the story whom the narrator addresses," 1991: 4) and iii) an implied reader imagined by the translator, all of whom "are roughly equivalent to their counterparts in the Source Text" (O'Sullivan 2003: 201). However, she also states that these three figures "can also differ greatly" (ibid.), as will be seen in the examples. In explaining that "the discursive presence of the translator can be located in every translated narrative" O'Sullivan underlines the fact that (203):

This particular voice would seem, to be more evident in children's literature than in other bodies of literature due to the specific, asymmetrical communication structure which characterizes texts that are written by adults for children."

In the first example, we find Felix's friend Dodie described as "a loud slurper" (2005: 1). The noun 'slurper' from the verb to 'slurp' ("to eat or drink with a loud sucking sound," $O C D$ ) of informal register is clear to English-speaking children who would be more than familiar with the word formation verb+-er, indicating the person who performs the action. It is not without a humorous touch - being a verb frequently used in comic strip captions, and referring to a transgressive way of eating. The translation normalizes the verb and makes the scene more genteel, thus losing the humorous touch, and transforming the typical child language into a more formal register: "Dodie [...] sips his soup loudly" (2009: 6). The definition of the verb used in the translation, 'sorbire,' is 'to drink in small sips.' It is a 'wellmannered' descriptive verb not frequently used in Italian and probably not even familiar to (let alone used by) an average 9-year-old child.

The second example is the one showing Felix's linguistic creativity. We read: "so other kids can't pinch my soup while I'm fogged up" (2005: 1). The expression "I'm fogged up" is an original way of saying that Felix's glasses were misted. The expression "to be fogged up" usually collocates with the object that is fogged up (e.g. 'My glasses are fogged up'). It is the unusual collocation of the expression with a personal pronoun subject ('I') that produces stylistic marking. In the translation the situation is normalized into a more formal syntactical and lexical form: "so as to avoid someone pinching it, taking advantage of my misty glasses" (2009: 6), thus lessening the marked impact of the original. The translation is also more explicit: 'while' is a temporal connective but 'taking advantage' explicates the connection - a direct form of accusation by the 'Italian' Felix that is not characteristic of the 'English' Felix, who tends to present facts as such without giving direct blame to people for these facts.

Still 'in the soup' we find another example of normalization. The verb " to stick" with reference to fingers ("I stick my fingers in the soup," (2005: 3) is formalized to "immerse" (2009: 8). Yet a verb of a similar register, 'ficcare' exists 
in Italian, which grasps the simplicity of this common transgressive action of a child, and is how an Italian child would most likely describe the action Felix is carrying out. Once again the description in Italian corresponds to an adult register rather than a child register, as in the original.

The following examples also show an apparent lack of attention to register. The register of the idiomatic expression 'up for grabs' is quoted by $O C D$ as "informal," but Felix's description: "my soup is up for grabs" (2005: 5) is rendered more genteelly in translation with the formal "my soup is at the disposal of anyone who wants it" (2009: 10). Likewise, the metaphor in informal age-based register "even when your tummy's stuffed with joy" (2005: 5) is translated into a more formal register, "even when you are filled up with joy" (2009: 10). Again Felix seems to talk in Italian more like an adult than like a child.

Finally the typical child's exclamation "Lucky Pig!" (2005: 6) is given a more refined tone in the Italian expression "Beato lui" (literally: Blessed be he!) (2009: 12). Such an expression is in Italy used more frequently by adults than by children.

The translator of Once presumably believes that the implied Italian child reader should be addressed through a different narrating voice, one that is more sophisticated and adult-like, perhaps in an attempt to produce a more educative narrating voice and one inspired by the construction she has made of the Italian child reader (Oittinen's 'child image') and on the established canons of Italian children's literature.

\section{Concluding Remarks}

We have seen that the Italian version of the children's book Once, set in Poland during the Second World War, and written originally in English, has undergone a series of transformations. These transformations seem to have been made in order to accommodate the text to the culture of the Italian child reader. This accommodation is immediately evident in the differences between the book covers. It has been shown how the Italian editor has produced a cover for his reading public that appeals to feelings and emotions, such as wonder and amazement, acceptable to Italian child culture. On the Italian cover priority is given to the more humorous aspects of the book, putting aside the harsher aspects of war referred to on the English cover.

With reference to the text itself, the examples given are representative of the Italian translation as a whole. The translator has continued the domestication strategy of translation initiated on the cover within the text itself. Firstly, it has been shown that marked sentence structures have often undergone a normalization process in translation, and that unusual lexical choices have often been converted 
to more usual unmarked choices. Secondly, we find a greater use of connectives and more explicitness in the translation. These strategies may be considered to be facilitating in that they obviously aim at giving the child reader greater assistance in comprehending the text, in line with the Italian culture, which tends to remove any obstacles in a child's path before s/he reaches them. However, this attempt at making the text more accessible to the Italian child reader has simultaneously led to the removal of challenges that the original author offered to the English-speaking reader and, even more noticeably, to a distinct change in the atmosphere and in the creative style of the original.

In what may mistakenly be first seen as a contradiction to the above statement is another aspect of the translation - the frequent transformation of an informal style to a more formal one. Such transformation reduces the impact of the original in that the original relies strongly on the realistic first-person singular child talk, while the translation frequently sounds more like an 'adult talk'. A more formal style is characteristic in Italy, as Taylor states: "Indeed Italian often appears to be more formal than English" (1998: 226). The tendency of the translator to formalise the register is therefore probably linked to the desire to conform to the norms of the Italian children's literary system, a system which reflects this linguistic tendency. The Italian children's literary system is in fact driven by a strongly educational aim which promotes a more formal literary style in children's stories in order to enrich their vocabulary and grammar. Hence the translator often seems to be the interpreter of what adults believe to be the child reader's requirements rather than the interpreter of the child reader's actual needs.

In conclusion, we see that the adoption of a domestication translation strategy has led to a certain domestication of the brutalities of war as described by the author in the original. The strategies adopted by the translator adapt the text presumably to make it compatible with the norms governing the Italian children's literary system and to accommodate it to the particular values of Italian culture and, specifically, to those regarding Italian children's upbringing. Such accommodation is common in translating for children, as Gideon Toury (1995) notes when he talks of contemporary norms of acceptability in the target culture which govern translation practice. However, the accommodation made by the translator of Once has led to a loss of much of the essential atmosphere and creativity of the original. The original presents the hard facts of wartime Poland and the tragedy of the Holocaust without any mediation, bluntly and honestly, through the eyes of a Jewish child. This child talks directly to the English-speaking child reader, but seems to talk more indirectly, through an adult filter, to Italian-speaking child readers. The latter are rarely presented with harsh brutal words or expressions, but they are rather presented with a more watered-down version, and they do not have to face the 
complexity of structure and meaning of the original, in that the translator provides them with greater explicitness and simplification. Italian child readers are protected and guided through the text, much as they are protected and guided in real life. However, the elements that have undergone transformation are exactly those that give power of atmosphere and nuances of meaning to the original, and one feels at the end of the day that Italian children are in some way deprived of savouring much of the dramatic and strikingly creative expressivity of the original. The translator may have underestimated the ability of Italian children to comprehend things which seem strange and unfamiliar, but children can surprise us, as the well-known children's writer, Astrid Lindgren, claims: "I believe that children have a marvellous ability to re-experience the most alien and distant things and circumstances" (as quoted in Stolt 1978: 132). In sum, the foreignization translation strategy, which aims at transmitting the particular flavour and style of the original, would have perhaps better reflected the stark realities of wartime Poland as portrayed in Once.

\section{References}

\section{Children's books}

Gleitzman, Morris. 2005. Once. London: Puffin Books.

Gleitzman, Morris. 2009. Una volta. (Trans. Loredana Serratore). Milan: Mondadori.

\section{Other sources}

Brake, Terence, Danielle Medina Walker \& Thomas Walker. 1995. Doing Business Internationally: The Guide to Cross-Cultural Success. Burr Ridge, IL: Irwin.

Douthwaite, John. 2000. Towards a Theory of Foregrounding. Alessandria: Edizione dell'Orso.

Genette, Gérard. 1997. Paratexts: Thresholds of Interpretation. Cambridge: CUP.

Hall, Edward. 1950/1990. The Silent Language. New York: Doubleday.

Halliday, Michael. 1985. An Introduction to Functional Grammar. London: Arnold.

Halliday, Michael. 1992. "New Ways of Meaning". In Thirty years of Linguistic Evolution, edited by Martin Pütz, 59-95. Philadelphia: John Benjamins.

Hofstede, Geert. 1991. Cultures and Organizations: Software of the Mind. London: McGraw-Hill.

\footnotetext{
We are grateful to Puffin Books (The Penguin Group) in London for giving Ms. Rowena Coles permission to include the facsimiles of their 2005 edition of the the front and back covers of the novel Once by M. Gleitzman in her paper to be published in both printed and electronic versions of this issue of Libri \& Liberi. Italian laws make it possible to publish book covers free of charge for academic purposes.

Zahvaljujemo izdavaču Puffin Books (The Penguin Group) iz Londona na ustupanju prava Roweni Coles za objavljivanje faksimila korica njihovoga izdanja knjige Once M. Gleitzmana iz 2005. u tiskanoj i u elektronskoj inačici ovoga broja časopisa Libri \& Liberi. Talijanski propisi omogućuju besplatno tiskanje korica knjiga $u$ akademske svrhe.
} 
Hollindale, Peter. 1997: 46. Signs of Childness in Children's Books. Stroud: Thimble Press. Katan, David. 1999. Translating Cultures. Manchester: St Jerome Publishing.

Lathey, Gillian. 2006. "The Translator Revealed: Didacticism, Cultural Mediation and Visions of the Child Reader in Translators' Prefaces." In Children's Literature in Translation, edited by Jan Van Coillie \& Walter P. Verschueren, 1-18. Manchester: St Jerome Publishing.

Lejeune, Philippe. 1975. Le Pacte autobiographique. Paris: Editions du Seuil.

Nida, Eugene. 1964. Towards a Science of Translation. Leiden: Brill.

Oittinen, Riitta. 2006. "No Innocent Act: On the Ethics of Translating for Children". In Children's Literature in Translation edited by Jan Van Coillie \& Walter P. Verschueren, 35-46. Manchester: St Jerome Publishing.

Orwell George. 1957. Inside the Whale and Other Stories. London: Penguin Books.

O'Sullivan, Emer. 2003. "Narratology Meets Translation Studies, or, The Voice of the Translator." Meta 48 (1-2): 197-207.

The Oxford Concise Dictionary. 10 ${ }^{\text {th }}$ edition. 1999. Oxford: Oxford University Press.

The Oxford Dictionary of English Grammar. 1994. Oxford: Oxford University Press.

Quirk, Randolph, et al. 1985. A Comprehensive Grammar of the English Language. London: Longman.

Stephens, John. 1999. "Analysing texts: linguistics and stylistics". In Understanding Children's Literature, edited by Peter Hunt, 73-85. London: Routledge.

Stolt, Birgit. 1978. "How Emil Becomes Michel: On the Translation of Children's Books." In Children's Books in Translation, edited by Göte Klingberg, 130-46. Stockholm: Almqvist and Wiksell.

Taylor, Christopher. 1998. Language to Language: A practical and Theoretical Guide for Italian/English Translators. Cambridge: CUP.

Toury, Gideon. 1995. Descriptive Translation Studies and Beyond. Amsterdam: John Benjamins Publishing.

Trompenaars, Fons. 1993. Riding the Waves of Culture. London: The Economist Books.

Ulyrich, Margherita. 1992. Translating Texts from Theory to Practice. Rapallo: Cideb Editore.

Venuti, Lawrence. 1995. The Translator's Invisibility. London: Routledge.

Victor, David. 1992. International Business Communication. London: HarperCollins.

Wall, Barbara. 1991. The Narrator's Voice: The Dilemma of Children's Fiction. London: Macmillan.

\section{Rowena Coles}

Sveučilište u Urbinu, Pedagoški fakultet (Università degli Studi Di Urbino 'Carlo Bo’) Urbino Universität, Pädagogische Fakultät

\section{Odomaćivanje ratne traume u prijevodu}

U radu se uspoređuje izvorno englesko izdanje romana za djecu Morrisa Gleitzmana Once (Jednom) s izdanjem njegova prijevoda na talijanski. Najprije se kratko istražuju pojmovi 'odomaćivanja' (domestication) $i$ 'otuđivanja' (foreignization) u kontekstu prijevodne prakse. Odomaćivanje nekoga teksta podrazumijeva približavanje toga teksta, kroz 
prijevod, kulturi podrazumijevanoga čitatelja, slici djetinjstva dotične kulture i utvrđenim konvencijama koje upravljaju dječjom književnošću u dotičnoj zemlji. Otuđivanje je strategija koja cilja na čuvanje što većega broja jezičnih i kulturnih razlikovnih obilježja izvornika. Dvije kulture u pozadini dvaju spomenutih jezika u radu se istražuju s posebnim osvrtom na to kako kulturne razlike utječu na pojam djetinjstva. Sama analiza počinje razmatranjem korica dvaju izdanja, imajući u vidu to da one, kao dio parateksta, imaju važnu ulogu u predstavljanju knjige na tržištu. Na temelju izabranih primjera iz teksta prijevoda otkrivaju se razlike u odnosu na izvornik na razinama sintakse, registra i jezične kreativnosti. Pritom su uočene tri pojave koje značajno utječu na ciljni tekst, a koje upućuju na proces normalizacije. Zaključuje se da se u prijevodu tematiziranoga romana primjenjuje strategija odomaćivanja, u skladu s kojom se tekst prilagođava kako bi ga se učinilo prihvatljivijim talijanskom dječjem čitatelju, ili barem onome za što odrasli Talijani vjeruju da je prikladnije za takve čitatelje. Posljedično, ratna je trauma u talijanskoj verziji postala manje okrutna i šokantna.

Ključne riječi: dječji čitatelj, kultura, odomaćivanje, olakšavanje, prijevod, normalizacija

\section{Domestizierung des Kriegstraumas in der Übersetzung}

Im Beitrag wird die englische Originalausgabe des Kinderromans Once von Morris Gleitzmann mit der italienischen Übersetzung verglichen. Einleitend werden kurz die Begriffe ,Domestizierung' (domestication) und ,Verfremdung'(foreignization) im Rahmen der Übersetzungspraxis besprochen. Unter Domestizierung eines Textes versteht man seine durch Übersetzung vermittelte Annäherung an die Kultur des impliziten Lesers, an das Kindheitsbild der betreffenden Kultur und an die festgelegten kinderliterarischen Konventionen dieses Landes. Verfremdung stellt eine Strategie dar, die auf Bewahrung je größerer Anzahl sprachlicher und kultureller Unterscheidungsmerkmale des Originals ausgerichtet ist. Die zwei im Hintergrund der angeführten Sprachen liegenden Kulturen werden im Beitrag insbesondere daraufhin erforscht, wie kulturelle Unterschiede auf den Begriff der Kindheit einwirken. Die Analyse beginnt mit der Besprechung des Umschlags der englischen und italienischen Ausgabe, weil dieser als Bestandteil des Paratextes bei der Vorstellung des Buches auf dem literarischen Markt eine große Rolle spielt. Anhand ausgewählter Beispiele aus der Übersetzung wird auf Textunterschiede auf der syntaktischen Ebene sowie in Hinblick auf das sprachliche Register und die sprachliche Kreativität hingewiesen. Diesbezüglich werden drei auf den Zieltext wesentlich einwirkenden Eigenschaften des Textes festgestellt, die auf einen Normalisierungsprozess hinweisen. Daraus wird geschlussfolgert, dass in der Romanübersetzung die Domestizierungsstrategie angewandt wird, wonach der Text den italienischen jungen Lesern, bzw. den Vorstellungen der erwachsenen Italienern darüber, was solchen Lesern entspricht, angepasst wird. Folglich wirkt das Kriegstrauma in der italienischen Version weniger brutal und schockierend.

Schlüsselwörter: kindlicher Leser, Kultur, Domestizierung, Erleichterung, Übersetzung, Normalisierung 